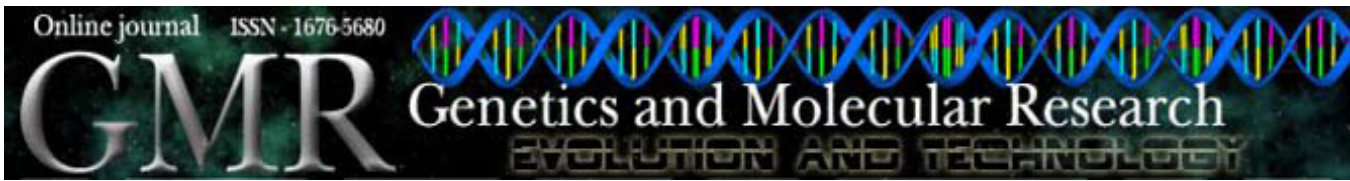

\title{
Cytogenetic studies in Brazilian marine Sciaenidae and Sparidae fishes (Perciformes)
}

\author{
I.V. Accioly and W.F. Molina \\ Departamento de Biologia Celular e Genética, Centro de Biociências, \\ Universidade Federal do Rio Grande do Norte, Natal, RN, Brasil \\ Corresponding author: W.F. Molina \\ E-mail: molinawf@yahoo.com.br
}

Genet. Mol. Res. 7 (2): 358-370 (2008)

Received January 15, 2008

Accepted February 11, 2008

Published April 22, 2008

\begin{abstract}
Fishes from the families Sciaenidae and Sparidae, the former comprising coastal species associated with shallow waters on the continental shelf and the latter composed of typically marine species, are of significant economic value. Karyotypic data are available for about $20 \%$ of the total number of species in these groups. In the present study, cytogenetic analyses were carried out in three Sciaenidae species, Menticirrhus americanus, Ophioscion punctatissimus and Pareques acuminatus, as well as in the sparid fish, Archosargus probatocephalus, using conventional staining (Giemsa) and Ag-nucleolar organizer regions (NORs) and C-banding techniques. The diploid values (2n) and number of chromosome arms were equal to 48 in all species analyzed. NORs were located at pericentromeric positions, equivalent to large heterochromatic blocks, in M. americanus (1st pair), O. punctatissimus (10th pair), $P$. acuminatus (2nd pair), and A. probatocephalus (3rd pair). Heterochromatin was detected at the centromeric position in most chromosome pairs, being more conspicuous among Scianidae members. The remarkable karyotypic conservativeness detected in these species is similar to that observed in other perciform groups previously studied, regarding both the number of acrocentric chromosomes and NOR location. However, unusual events of heterochromatinization seem to have taken place along the karyotypic evolution of members of the family Sciaenidae. For the family Sparidae, distinct cytotypes between samples of Northeast Brazil and those previously analyzed on the southeastern coast were identified, suggesting that putative biogeographic barriers
\end{abstract}


could be present throughout both regions on South Atlantic coast.

Key words: Fish cytogenetics; Sciaenidae; Sparidae;

Chromosome stasis

\section{INTRODUCTION}

Evolutionary stasis has often been referred to as a common phenomenon, whether at a higher or a lower degree, in the karyotypic evolution of Perciformes species (Molina, 2006). Such condition is particularly notorious along the evolution of several fish families that lack a significant relationship between karyotypic changes and time of divergence.

Amongst the examples of marine fishes characterized by chromosomal stasis we can point out the members of the family Scianidae (croakers and drums), whose representatives share several symplesiomorphic cytogenetic features with other Perciformes groups, such as $2 n=48$, fundamental number $(\mathrm{FN})=48$, single and pericentromeric nucleolar organizer regions (NORs), scarcity of conspicuous heterochromatic blocks and a typical symmetrical karyotype (Galetti Jr. et al., 2006). Such scenario hinders the application of cytogenetic traits as efficient cytotaxonomic and phylogenetic markers within this fish group.

However, other families of Perciformes, such as Sparidae (porgies), show a higher karyotypic diversification $(\mathrm{FN}=48-70)$. Although members of this family have been relatively well studied under a cytogenetic focus in the Indian and Pacific Oceans and Mediterranean Sea (Cataudela et al., 1980; Chakraborty, 1986; Vitturi et al., 1992), there are few available reports about sparids in the Atlantic (Barreto Neto et al., 1998).

The family Sparidae comprises nearly 37 genera and 125 species, and 27 of them were karyotyped. Members of this family are widespread over tropical and temperate waters in the Atlantic, Indian and Pacific Oceans. Most sparids live typically in salt water, with a few freshwater species. They are carnivores, preying mainly on benthonic invertebrates. Cases of synchronic and asynchronic hermaphroditism are frequent in this fish family (Froese and Pauly, 2007).

The scianids represent an important fishery resource and, just like sparids, are found throughout the Atlantic, Indian and Pacific Oceans (Nelson, 2006), comprising about 282 species distributed into 70 genera. They are marine coastal fishes associated with sandy bottoms and reproduce in estuaries, bays or open sea, producing eggs dispersed by tidal currents (Santos et al., 2006). So far, karyotypes are reported for 29 of the total number of Scianidae species (Froese and Pauly, 2007), such as, for instance, the 11 marine species analyzed by LeGrand and Fitzsimons (1988), two South American species (Gomes et al., 1983a,b; Pereira et al., 1988), and three Indian species as well (Chakraborty, 1986; Tripathy and Das, 1988), among others. Most scianids have a diploid number of $2 \mathrm{n}=48$ chromosomes, nearly all acrocentric (Feldberg et al., 1999).

In order to increase the available cytogenetic reports on both fish families, the goal of the present study was to characterize three marine species of the family Scianidae (Menticirrhus americanus, Ophioscion punctatissimus and Pareques acuminatus) and one species of the family Sparidae (Archosargus probatocephalus), through conventional staining, Ag-NOR staining and C-banding, helping to identify the evolutionary processes within these fish groups.

\section{MATERIAL AND METHODS}

Specimens of $O$. punctatissimus, $M$. americanus, P. acuminatus, and A. probatocephalus 
were collected at three sites on the coastline of the State of Rio Grande do Norte, Northeast Brazil:

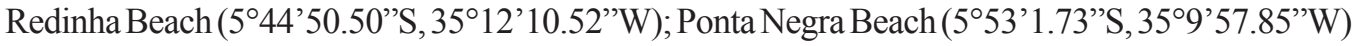
and Búzios Beach (60'28.12”S, 356'19.23”W).

Prior to chromosome preparations, the specimens were mitotically stimulated by peritoneal inoculation of yeast suspension (glucose solution with Saccharomyces cerevisae at $1 \mathrm{~mL} / 100 \mathrm{~g}$ body weight) for $24 \mathrm{~h}$ (Lee and Elder, 1980). To reduce the mortality rate in this step, mitotic stimulation was also performed by inoculation of a complex of bacterial and fungal antigens Munolan ${ }^{\circledR}$ (Allergan Frumtost) (76 mg suspended in $2.5 \mathrm{~mL}$ distilled water), at a proportion of $1 \mathrm{~mL} / 50 \mathrm{~g}$ body weight for 24 to $48 \mathrm{~h}$ (Molina, 2001). Mitotic chromosomes were obtained by in vitro technique according to Gold et al. (1990). NORs and heterochromatic regions were identified by the methods described by Howell and Black (1980) and Sumner (1972), respectively. To establish the number of chromosome arms (FN), acrocentric chromosomes were classified as uni-armed. In order to allow a reliable comparison, the FN in previously reported data was recalculated based on the same criterion.

\section{RESULTS}

The chromosomal analyses in the four species showed a common diploid value of 48 chromosomes (Figures 1-4). The chromosomes were classified as acrocentric $(\mathrm{FN}=48)$, with subtle size differences among chromosome pairs. Secondary constrictions related to NORs were observed in all species studied.

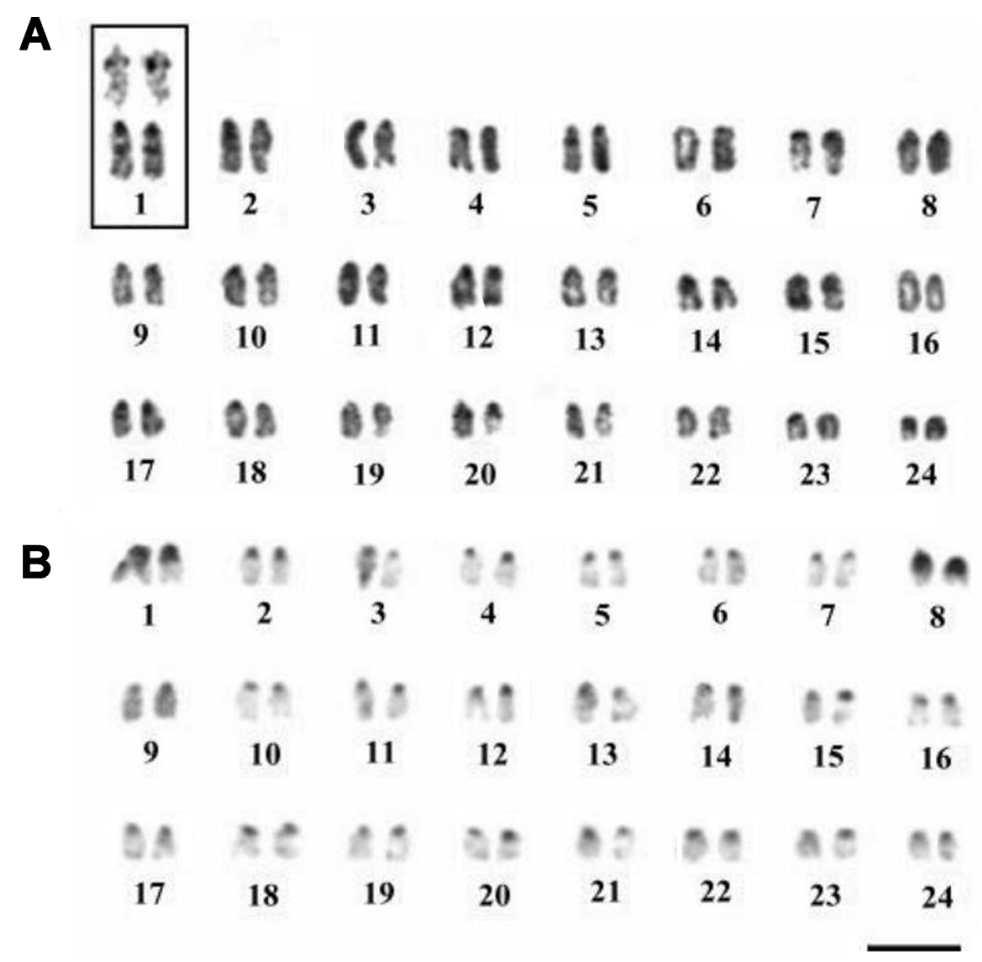

Figure 1. Karyotype of Menticirrhus americanus. A. Giemsa staining, $2 \mathrm{n}=48 \mathrm{a}$. In detail, the NOR-bearing pair (1st pair). B. C-banding. Bar $=5 \mu \mathrm{m}$. 


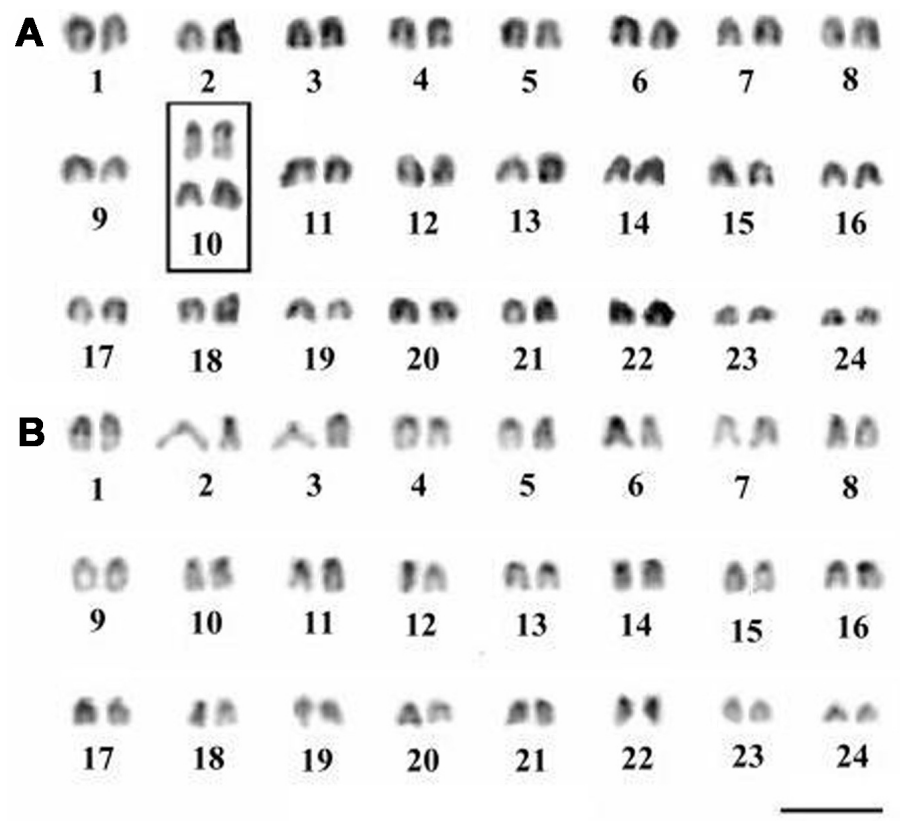

Figure 2. Karyotype of Ophioscion punctatissimus. A. Giemsa staining, $2 \mathrm{n}=48 \mathrm{a}$. In detail, the NOR-bearing pair (10th pair). B. C-banding. Bar $=5 \mu \mathrm{m}$.

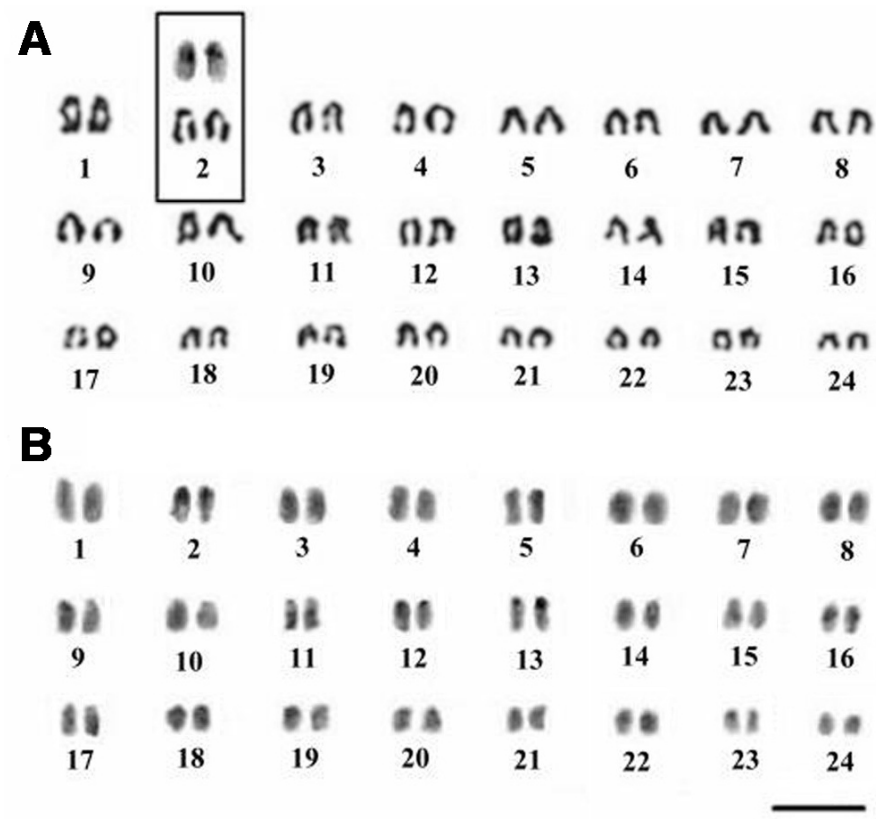

Figure 3. Karyotype of Pareques acuminatus. A. Giemsa staining, $2 \mathrm{n}=48 \mathrm{a}$. In detail, the NOR-bearing pair (2nd pair). B. C-banding. Bar $=5 \mu \mathrm{m}$. 


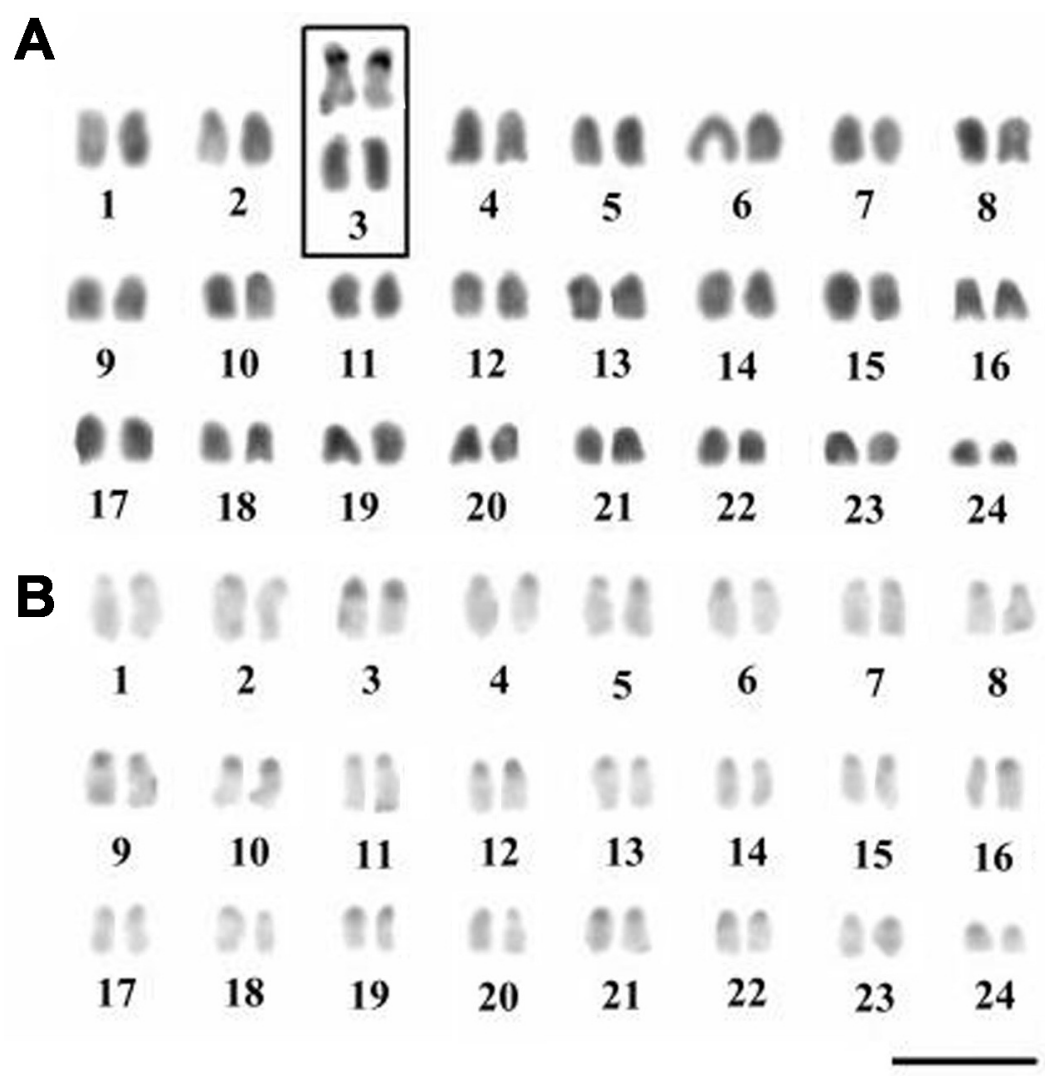

Figure 4. Karyotype of Archosargus probatocephalus. A. Giemsa staining, $2 \mathrm{n}=48 \mathrm{a}$. In detail, the NOR-bearing pair (3rd pair). B. C-banding. Bar $=5 \mu \mathrm{m}$.

The Ag-NOR sites in both Scianidae and Sparidae species were single and located at the pericentromeric position on distinct chromosome pairs according to the species. NORs were detected on the 1st pair in M. americanus, on the 2nd pair in the reef species $P$. acuminatus, on the 10th pair in O. punctatissimus, and on the 3rd pair in the sparid $A$. probatocephalus.

The pattern of heterochromatin distribution was also similar in the karyotype of the species analyzed, which showed heterochromatic blocks mainly located in the centromeric region. However, comparing the C-banded karyotypes, it was possible to observe a higher content of heterochromatin within Sciaenidae than in the Sparidae species. Pericentromeric and somewhat conspicuous blocks were identified on NORs and in some specific chromosomes. In M. americanus, a large heterochromatic segment was detected comprising up to two-thirds of the 8th chromosome pair (Figure 1B). A greater variation in heterochromatin content was observed in O. punctatissimus which had several chromosome pairs $(1,2,4,5,6,10,16,17)$ bearing heterochromatic blocks at the pericentromeric position (Figure 2B). 


\section{DISCUSSION}

Karyotypic stasis is more often detected in marine fish species. The marine realm, due to its high dispersal potential related to transportation of pelagic larvae through tidal flows and less effective biogeographic barriers, favors a higher connectivity among distant populations and, thus, leads to a reduced rate of chromosomal divergence. These characteristics, hypothetically, explain the maintenance of a stable karyotypic structure, resistant to chromosomal diversification processes, in most marine fish species (Molina, 2006).

Several reports have demonstrated that the degree of karyotypic differentiation (number of changes in FN values) in some families of marine reef Perciformes (i.e., Pomacentridae; Labridae) is inversely related to the dispersive potential provided by the extent of pelagic larval duration of each species (Molina and Galetti Jr., 2004; Molina, 2006; Sena and Molina, 2007).

A remarkable example of chromosomal stability within marine perciforms is present in the family Sciaenidae (Table 1). Such trend in chromosomal conservativeness, both numerical and structural, is corroborated by the present results obtained in the scianids $M$. americanus, O. punctatissimus and P. acuminatus.

\section{Table 1. Review of the cytogenetic data in the family Sciaenidae.}

\begin{tabular}{|c|c|c|c|c|c|c|c|}
\hline Species & $2 n$ & FN & $\mathrm{a} / \mathrm{st}$ & $\mathrm{m} / \mathrm{sm}$ & NORs & C-banding & References \\
\hline Aplodinotus grunniens & 48 & 48 & $48 \mathrm{a}$ & - & - & - & LeGrande and Fitzsimons, 1988 \\
\hline Bairdiella chrysoura & 48 & 48 & $48 \mathrm{a}$ & - & - & - & LeGrande and Fitzsimons, 1988 \\
\hline B. chrysoura & 52 & 52 & $52 \mathrm{a}$ & - & - & - & Gregory et al., 1980 \\
\hline Cynoscion acoupa & 48 & 48 & $48 \mathrm{a}$ & - & - & - & Brum, 1996 \\
\hline C. arenarius & 48 & 50 & $46 \mathrm{a} / 2 \mathrm{st}$ & - & - & - & Fitzsimons et al., 1985 \\
\hline C. arenarius & 48 & - & - & - & - & - & Ramirez, 1980 \\
\hline C. nebulosus & 48 & 50 & $46 a / 2 s t$ & - & - & - & Fitzsimons et al., 1985 \\
\hline C. nebulosus & 50 & 50 & $50 \mathrm{a}$ & - & - & - & Arkhipchuk, 1999 \\
\hline Johnius belangerii & 48 & 48 & $48 \mathrm{a}$ & - & - & - & Chakraborty, 1986 \\
\hline$J$. borneensis / J. vogleri & 48 & 48 & $48 \mathrm{a}$ & - & - & - & Patro and Prasad, 1979 \\
\hline J. carutta & 48 & 48 & $48 \mathrm{a}$ & - & - & - & Patro and Prasad, 1979 \\
\hline J. dorsalis & 48 & 48 & $48 \mathrm{a}$ & - & - & - & Raghunath and Prasad, 1980; Chanda, 1989 \\
\hline J. dussumieri & 48 & 48 & $48 \mathrm{a}$ & - & - & - & Chanda, 1989 \\
\hline Kathala axillaris & 48 & 48 & $48 \mathrm{a}$ & - & - & - & Tripathy and Das, 1988 \\
\hline Leiostomus xanthurus & 48 & 48 & $48 \mathrm{a}$ & - & - & - & LeGrande and Fitzsimons, 1988 \\
\hline Menticirrhus americanus & 48 & 48 & $48 \mathrm{a}$ & - & - & - & Gomes et al., $1983 b$ \\
\hline M. americanus & 48 & 48 & $48 \mathrm{a}$ & - & - & - & Arkhipchuk, 1999 \\
\hline M. americanus & 48 & 48 & $48 \mathrm{a}$ & - & s (1st pair); p & $\mathrm{c}, \mathrm{p}$ & Present study \\
\hline M. littoralis & 48 & 48 & $48 \mathrm{a}$ & - & $\mathrm{s}$ & $\mathrm{c}, \mathrm{p}$ & Reggi et al., 1986 \\
\hline Micropogonias furnieri & 48 & 48 & $48 \mathrm{a}$ & - & - & - & Gomes et al., 1983a; Pereira et al., 1988 \\
\hline M. furnieri & 48 & 48 & $42 \mathrm{a} / 6 \mathrm{st}$ & - & $\mathrm{s}$ & $\mathrm{c}$ & Brum, 1996 \\
\hline M. undulates & 48 & 48 & $48 \mathrm{a}$ & - & - & - & LeGrande and Fitzsimons, 1988 \\
\hline Nibea mitsukurii & 48 & 48 & $48 \mathrm{a}$ & - & - & - & Ojima and Kikuno, 1987 \\
\hline Ophioscion punctatissimus & 48 & 48 & $48 \mathrm{a}$ & - & $\mathrm{s}$ (10th pair); p & $\mathrm{c}, \mathrm{p}$ & Present study \\
\hline Otolithes cuvieri & 48 & 48 & $48 \mathrm{a}$ & - & - & - & Chakraborty and Kagwade, 1989 \\
\hline Otolithoides pama & 48 & 48 & $48 \mathrm{a}$ & - & - & - & Khuda-Bukhsh and Nayak, 1990 \\
\hline Paranibea semiluctuosa & 48 & 48 & $48 \mathrm{a}$ & - & - & - & Chakraborty, 1986 \\
\hline Pareques acuminatus & 48 & 48 & $48 \mathrm{a}$ & - & $\mathrm{s}$ (2nd pair); $\mathrm{p}$ & $\mathrm{p}$ & Present study \\
\hline Plagioscion sp & 48 & $48-50$ & $48-46$ & $2 \mathrm{~m}$ & $\mathrm{~m}(1 \mathrm{st} \mathrm{a} / 1 \mathrm{st} \mathrm{m}) ; \mathrm{p}$ & $\mathrm{p}$ & Feldberg et al., 1999 \\
\hline P. squamosissimus & 48 & 48 & $48 \mathrm{a}$ & - & $\mathrm{s}(24 \mathrm{th}) ; \mathrm{p}$ & $\mathrm{p}$ & Feldberg et al., 1999 \\
\hline Pogonias cromis & 48 & 48 & $48 \mathrm{a}$ & - & - & - & LeGrande and Fitzsimons, 1988 \\
\hline Protonibea diacanthus & 48 & 48 & $48 \mathrm{a}$ & - & - & - & Chakraborty and Kagwade, 1989 \\
\hline Sciaena umbra & 48 & 48 & $48 \mathrm{a}$ & - & - & - & Vasil'ev, 1978 \\
\hline Sciaenops ocellatus & 48 & 48 & $48 \mathrm{a}$ & - & $\mathrm{s}$ & Go & Gold et al., 1988; LeGrande and Fitzsimons, 1988 \\
\hline Umbrina coroides & 46 & 46 & $46 \mathrm{a}$ & - & - & - & Brum, 1996 \\
\hline
\end{tabular}

$\mathrm{FN}=$ fundamental number; $\mathrm{a}=$ acrocentric $; \mathrm{st}=$ subtelocentric $; \mathrm{m}=$ metacentric $; \mathrm{sm}=$ submetacentric; $\mathrm{p}=$ pericentromeric; $\mathrm{c}=$ centromeric; $\mathrm{s}=$ single nucleolar organizer region $(\mathrm{NOR}) ; \mathrm{m}=$ multiple NORs. 
The presence of 48 chromosomes, widespread in karyotypes of Perciformes, including several families and suborders, has been regarded as a primitive condition for this fish group (Galetti Jr. et al., 2000, 2006). Such diploid value, associated with the exclusive presence of acrocentric chromosomes $(\mathrm{FN}=48)$, reflects a synapomorphic condition for modern teleosteans (Brum and Galetti Jr., 1997). Both structural and numerical conservativeness is extensively found within the family Scianidae, although variations related to increase or reduction of diploid number have already been reported, ranging from $2 n=46$ in Umbrina coroides (Brum, 1996) to $2 n=52$ in Bairdiella chrysura. The latter is characterized by a chromosomal variation determined by fissions, with cytotypes varying from $2 \mathrm{n}=48$ to 52 chromosomes (Gregory et al., 1980). Moreover, a few species may show variation in the number of chromosome arms related to pericentric inversions during karyotypic evolution (Takai and Ojima, 1987; Feldberg et al., 1999). However, this variation seems to be insignificant when compared to other Perciformes families, such as Nototheniidae $(2 \mathrm{n}=22-58 ; \mathrm{FN}=44-88)$ or Bathydraconidae $(2 \mathrm{n}=20-48 ; \mathrm{FN}=40-58)$ (Pisano and Ozouf-Costaz, 2000).

Within the family Sparidae, 22\% of the species were karyotyped, revealing a higher degree of chromosomal variation regarding FN values when compared to Scianidae. The number of chromosome arms in this family may range from 48 to 70 , with the presence of acrocentric, subtelocentric and submetacentric chromosomes. Most of the species karyotyped have been studied by different authors, sometimes showing discordant FN values for a single species (e.g., Acanthopagrus latus) (Table 2). Despite such variation in the chromosome formulae, the diploid number is still conserved among sparids $(2 n=48)$, like the majority of marine Perciformes families studied so far (Sola et al., 1981; Galetti Jr. et al., 2000).

Comparative analyses about the frequency of chromosomal rearrangements in Atlantic Perciformes species have revealed some evolutionary trends within distinct groups (Galetti Jr. et al., 2006). The families Chaetodontidae, Haemulidae, Serranidae, and Sciaenidae were characterized by a low frequency, or even absence, of apparent structural chromosomal rearrangements (inversions, fusions and fissions). Such karyotypic conservativeness may be related to an evolutionary process based on chromosomal microdiversification driven by nondetectable changes in the karyotype.

The conserved pattern of karyotypic evolution in marine Perciformes has been associated with the interaction of distinct aspects, such as lack of well-defined geographic barriers, high inter-populational gene flow, dispersal potential of adults and/or larvae, and the common presence of large populations in marine ecosystems (Molina, 2006). The combined action of these features would restrain the fixation of polymorphic chromosomal rearrangements and lead to a reduced karyotypic diversification. This hypothesis is corroborated by the identification of some marine species bearing derived karyotypes that lack one or more of such features (Molina and Galetti Jr., 2004).

However, even freshwater Scianidae species, such as Plagioscion squamosissimus and Plagioscion sp, inhabiting inland waters and, therefore, more propitious to karyotypic diversification by the presence of more effective geographic barriers, share a similar karyotype structure $(2 \mathrm{n}=48$ acrocentric) also found in their related marine representatives (Feldberg et al., 1999). These data, coupled with the present results, reinforce that, besides environmental partitions, whether related to physical or biological features, there should be an intrinsic condition for the maintenance of stable karyotypes in some groups. 
Cytogenetic studies in Sciaenidae and Sparidae fishes

\begin{tabular}{|c|c|c|c|c|c|c|c|}
\hline Species & $2 n$ & FN & $\mathrm{a} / \mathrm{st}$ & $\mathrm{m} / \mathrm{sm}$ & NORs & C-banding & References \\
\hline Acanthopagrus latus & 48 & 58 & $38 \mathrm{a} / 6 \mathrm{st}$ & $4 \mathrm{sm}$ & - & - & Murofushi et al., 1983 \\
\hline " & 48 & 58 & $38 \mathrm{a} / 4 \mathrm{st}$ & $4 \mathrm{~m} / 2 \mathrm{sm}$ & - & - & $\begin{array}{c}\text { Lin and Liu, 1989; Jiahan } \\
\text { and Lisha, } 1989\end{array}$ \\
\hline $\begin{array}{l}\text { Archosargus } \\
\text { probatocephalus }\end{array}$ & 48 & 48 & $48 \mathrm{a}$ & - & s (1a) & $\mathrm{c}$ & Present study \\
\hline " & 48 & 53 & $43 \mathrm{a}$ & $1 \mathrm{~m} / 4 \mathrm{sm}$ & - & - & Law et al., 1978 \\
\hline$"$ & 48 & 50 & $46 a$ & $2 \mathrm{~m}$ & - & - & Arkhipchuk, 1999 \\
\hline$"$ & 48 & 60 & $36 \mathrm{a}$ & $4 \mathrm{~m} / 8 \mathrm{sm}$ & - & - & Fitzsimons et al., 1985 \\
\hline $\begin{array}{l}\text { Acanthopagrus } \\
\text { schlegelii czerskii }\end{array}$ & 48 & 58 & $38 \mathrm{st}$ & $6 \mathrm{~m} / 4 \mathrm{sm}$ & - & - & Liu and Tian, 1991 \\
\hline A. schlegelii schlegelii & 48 & 58 & $38 \mathrm{a} / 4 \mathrm{st}$ & $6 \mathrm{sm}$ & - & - & Murofushi et al., 1983 \\
\hline " & 48 & 56 & $40 \mathrm{a}$ & $8 \mathrm{sm}$ & - & - & Kim et al., 1989 \\
\hline Boops boops & 48 & 54 & $42 \mathrm{a}$ & $4 \mathrm{~m} / 2 \mathrm{sm}$ & - & - & Cano et al., 1981 \\
\hline Chrysophrys auratus & 48 & 50 & $46 \mathrm{a} / 2 \mathrm{st}$ & - & - & - & $\begin{array}{c}\text { Nishikawa and Karasawa, 1972; } \\
\text { Liu and Tian, } 1991\end{array}$ \\
\hline Dentex tumifrons & 48 & 52 & $44 \mathrm{a} / 4 \mathrm{st}$ & - & - & - & Arkhipchuk, 1999 \\
\hline$"$ & 48 & 48 & $46 a / 2 s t$ & - & - & - & Murofushi et al., 1983 \\
\hline Diplodus annularis & 48 & 54 & $42 \mathrm{a} / \mathrm{st}$ & $2 \mathrm{~m} / 4 \mathrm{sm}$ & - & - & Arkhipchuk, 1999 \\
\hline$"$ & 48 & 56 & $40 \mathrm{a} / 2 \mathrm{st}$ & $6 \mathrm{~m} / \mathrm{sm}$ & - & - & Cataudella et al., 1980 \\
\hline$"$ & 48 & 54 & $42 \mathrm{a} / \mathrm{st}$ & $6 \mathrm{~m} / \mathrm{sm}$ & - & - & Vitturi et al., 1996 \\
\hline$"$ & 48 & 56 & $40 \mathrm{a} / 2 \mathrm{st}$ & $6 \mathrm{~m}$ & - & - & Sola and Cataudella, 1978 \\
\hline$"$ & 48 & 54 & $42 a$ & $2 \mathrm{~m} / 4 \mathrm{sm}$ & - & - & Vasil'ev, 1978 \\
\hline D. argenteus argenteus & 48 & 48 & $48 \mathrm{a}$ & - & - & - & Brum, 1996 \\
\hline D. bellottii & 46 & 54 & $38 \mathrm{a} / \mathrm{st}$ & $2 \mathrm{~m} / 6 \mathrm{sm}$ & $\mathrm{m}(1 \mathrm{a}, 1 \mathrm{sm})$ & - & Amores et al., 1993 \\
\hline D. cervinus cervinus & 48 & 54 & - & - & - & - & Amores et al., 1993 \\
\hline D. puntazzo & 48 & 54 & - & - & m (6 pairs) & - & Vitturi et al., 1996 \\
\hline D. sargus sargus & 48 & 56 & $40 \mathrm{a} / 2 \mathrm{st}$ & $6 \mathrm{~m} / \mathrm{sm}$ & - & - & Cataudella et al., 1980 \\
\hline$"$ & 48 & 54 & $42 \mathrm{a} / 2 \mathrm{st}$ & $2 \mathrm{~m} / 2 \mathrm{sm}$ & - & - & Cano et al., 1981 \\
\hline$"$ & 48 & 54 & $42 \mathrm{a} / \mathrm{st}$ & $6 \mathrm{~m} / \mathrm{sm}$ & - & - & Vitturi et al., 1996 \\
\hline$"$ & 48 & 56 & $40 \mathrm{a} / 2 \mathrm{st}$ & $6 \mathrm{~m}$ & - & - & Sola and Cataudella, 1978 \\
\hline D. vulgaris & 48 & 54 & $42 \mathrm{a} / 2 \mathrm{st}$ & $2 \mathrm{~m} / 2 \mathrm{sm}$ & - & - & Cano et al., 1981 \\
\hline$"$ & 48 & 54 & - & - & - & - & Vitturi et al., 1996 \\
\hline Evynnis japonica & 48 & 50 & $46 \mathrm{a}$ & $2 \mathrm{sm}$ & - & - & $\begin{array}{l}\text { Murofushi et al., 1983; } \\
\text { Manna, } 1989\end{array}$ \\
\hline Lagodon rhomboids & 48 & 54 & $42 \mathrm{a}$ & $6 \mathrm{~m}$ & - & - & Fitzsimons and Parker, 1985 \\
\hline Lithognathus mormyrus & 48 & 70 & $26 \mathrm{a} / 16 \mathrm{st}$ & $6 \mathrm{~m} / \mathrm{sm}$ & - & - & $\begin{array}{l}\text { Cataudella et al., } 1980 \\
\text { Sola et al., } 1981\end{array}$ \\
\hline$"$ & 48 & 70 & $26 a / 16 s t$ & $6 \mathrm{~m}$ & - & - & Sola and Cataudella, 1978 \\
\hline$"$ & 48 & 52 & $44 a$ & $2 \mathrm{~m} / 2 \mathrm{sm}$ & - & - & Cano et al., 1981 \\
\hline Oblada melanura & 46 & 58 & $34 \mathrm{a} / 6 \mathrm{st}$ & $6 \mathrm{~m} / \mathrm{sm}$ & - & - & $\begin{array}{l}\text { Cataudella et al., 1980; } \\
\text { Sola et al., } 1981\end{array}$ \\
\hline$"$ & 46 & 58 & $34 \mathrm{a} / 6 \mathrm{st}$ & $6 \mathrm{~m}$ & - & - & Sola and Cataudella, 1978 \\
\hline Pagellus acarne & 48 & 56 & $40 \mathrm{a}$ & $2 \mathrm{~m} / 6 \mathrm{sm}$ & - & - & Arkhipchuk, 1999 \\
\hline$"$ & 48 & 52 & $44 a$ & $4 \mathrm{~m}$ & - & - & Cano et al., 1981 \\
\hline$"$ & 48 & 56 & $40 \mathrm{a} / 6 \mathrm{st}$ & $2 \mathrm{~m}$ & - & - & Sola et al., 1981 \\
\hline$"$ & 48 & 56 & $40 \mathrm{a} / 6 \mathrm{st}$ & $2 \mathrm{~m}$ & - & - & $\begin{array}{l}\text { Sola and Cataudella, 1978; } \\
\quad \text { Cataudella et al., } 1980\end{array}$ \\
\hline P. erythrinus & 48 & 48 & $48 \mathrm{a}$ & - & - & - & $\begin{array}{l}\text { Sola and Cataudella, 1978; } \\
\text { Cataudella et al., 1980; } \\
\text { Sola et al., 1981; }\end{array}$ \\
\hline Pagrus auriga & 48 & 48 & $48 \mathrm{a}$ & - & s & - & Vitturi et al., 1992 \\
\hline P. caeruleostictus & 48 & 50 & - & - & s & - & Vitturi et al., 1992 \\
\hline P. major & 48 & 50 & $46 a / 2 s t$ & - & - & - & $\begin{array}{c}\text { Nishikawa and Karasawa, 1972; } \\
\text { Murofushi et al., 1983; } \\
\text { Yu et al., } 1993\end{array}$ \\
\hline
\end{tabular}


Table 2. Continued.

\begin{tabular}{|c|c|c|c|c|c|c|c|}
\hline Species & $2 n$ & $\mathrm{FN}$ & $\mathrm{a} / \mathrm{st}$ & $\mathrm{m} / \mathrm{sm}$ & NORs & C-banding & References \\
\hline P. major & 48 & 48 & $48 \mathrm{a}$ & - & - & - & Kim et al., 1989 \\
\hline P. pagrus & 48 & 50 & - & - & $\mathrm{s}$ & - & Vitturi et al., 1992 \\
\hline$"$ & 48 & 50 & $46 \mathrm{a}$ & $2 \mathrm{sm}$ & - & - & Barreto Neto et al., 1998 \\
\hline Rhabdosargus sarba & 48 & 60 & $36 \mathrm{a} / 6 \mathrm{st}$ & $6 \mathrm{sm}$ & - & - & Murofushi et al., 1983 \\
\hline Sarpa salpa & 48 & 64 & $32 \mathrm{a} / 10 \mathrm{st}$ & $6 \mathrm{~m}$ & - & - & $\begin{array}{l}\text { Sola and Cataudella, 1978; } \\
\text { Cataudella et al., 1980; } \\
\text { Sola et al., } 1981\end{array}$ \\
\hline$"$ & 48 & 58 & $38 \mathrm{a}$ & $2 \mathrm{~m} / 8 \mathrm{sm}$ & - & - & Arkhipchuk, 1999 \\
\hline$"$ & 48 & 54 & $42 \mathrm{a} / 2 \mathrm{st}$ & $2 \mathrm{~m} / 2 \mathrm{sm}$ & - & - & Cano et al., 1981 \\
\hline Sparus aurata & 48 & 66 & $30 \mathrm{a} / 10 \mathrm{st}$ & $8 \mathrm{~m} / \mathrm{sm}$ & $\mathrm{s}$ & - & $\begin{array}{c}\text { Sola and Cataudella, 1978; } \\
\text { Vitturi et al., 1992; } \\
\text { Cataudella et al., } 1980\end{array}$ \\
\hline
\end{tabular}

$\mathrm{FN}=$ fundamental number; $\mathrm{a}=$ acrocentric; $\mathrm{st}=$ subtelocentric; $\mathrm{m}=$ metacentric; $\mathrm{sm}=$ submetacentric; $\mathrm{c}=$ centromeric; $\mathrm{s}=$ single nucleolar organizer region $(\mathrm{NOR}) ; \mathrm{m}=$ multiple NORs.

Population studies based on mtDNA sequences in the scianid Macrodon ancylodon along the Brazilian coast identified genetic differences between populations from north-northeastern shore, under influence of warm waters (tropical clade), and populations on south-southeastern coast, inhabiting cold waters from the Malvinas current (subtropical clade) (Santos et al., 2006). The distribution of both clades, presenting a high level of genetic differentiation, was related to differences in water temperature and tidal flow (physical barrier), and reinforced by a putative larval retention and low migration rate of adult individuals. Inversely, no apparent karyotypic differences were found after cytogenetic analyses in samples of Menticirrhus americanus (Scianidae) from Northeastern Brazil in relation to previous studies carried out in populations from the southeastern shore (Gomes et al., 1983b), albeit both collection sites are more than $2000 \mathrm{~km}$ apart. However, the lack of karyotypic variation between these samples needs to be confirmed through refined techniques of chromosomal mapping using hybridization with specific DNA probes or replication banding.

On the other hand, the cytogenetic data in Sparidae show a remarkable diversification regarding karyotype formulae among species or populations of a single species, such as Lithognathus mormyrus ( $\mathrm{FN}=52,54,70)$ (Sola and Cataudella, 1978; Cataudella et al., 1980; Sola et al., 1981; Cano et al., 1981). This feature was also verified in A. probatocephalus, since the individuals analyzed in the present study showed a distinct karyotype formula $(\mathrm{FN}=48)$ in relation to previous reports in populations of the North America coast $(\mathrm{FN}=53$ and 60$)$ (Fitzsimons et al., 1985). Such remarkable karyotypic diversification in allopatric samples of A. probatocephalus indicates a level of chromosomal modification suggesting that both populations actually refer to different species lacking a proper denomination.

Few cytogenetic reports in the families Sciaenidae and Sparidae refer to structural karyotype aspects, constraining their application as cytotaxonomic markers. A single NOR in the pericentromeric region has been considered a basal condition within Perciformes (Affonso et al., 2001), and they are widespread within Scianidae. However, the NOR-bearing chromosome pair can differ among species, such as in Plagioscion sp (1st pair) and P. squamosissimus (24th pair) (Feldberg et al., 1999) or in M. americanus (1st pair), P. acuminatus (2nd pair) and O. punctatissimus (10th pair), presently studied.

NORs within the family Sparidae present a more diversified pattern of karyotypic evolution. Therefore, species bearing a single NOR (e.g., A. probatocephalus) or multiple 
NORs (Diplodus bellottii; Amores et al., 1993; D. puntazzo; Vitturi et al., 1996) have been identified (Table 2).

There are several reports in marine species showing the co-location of NORs and heterochromatin (Galetti Jr. et al., 2000; Affonso and Galetti Jr., 2005; Molina and Bacurau, 2006; Sena and Molina, 2007; among others), similar to what was observed in the karyotype of the species analyzed herein (M. americanus, O. punctatissimus, P. acuminatus, and A. probatocephalus).

In general, the distribution of heterochromatic segments at the centromeric and pericentromeric position identified in Atlantic scianids follows the pattern previously reported in other species of this family (Reggi et al., 1986; Feldberg et al., 1999). A similar heterochromatin distribution pattern was also observed in the sparid A. probatocephalus.

Phylogenetic studies based on internal body structures (swim bladder and otoliths) placed Sciaenidae as a closely related phylogenetic group to Haemulidae (Trewavas, 1977; Chao, 1978, 1986; Schwarzhans, 1993). Yet, the cytogenetic data available for Scianidae and Haemulidae are not reliable enough to corroborate such phylogenetic affinity since they share symplesiomorphic karyotypic features also present in several other families of Perciformes (Molina, 2006).

As for the phylogeny of Sparidae, morphological comparisons suggest that this family would be closely related to Caesionidae, Haemulidae, Lethrinidae, Lutjanidae, and Nemipteridae (Schultz, 1953; Jordan and Fesler, 1983). Analyses based on mtDNA sequences have corroborated such relationship (Orrell and Carpenter, 2004), and further indicate that the six Sparidae subfamilies (Boopsinae, Denticinae, Diplodinae, Pagellinae, Pagrinae, and Sparinae) are not monophyletic, suggesting that the characteristic dentition and feeding behavior of each subfamily have both arisen independently at different evolutionary stages. The occurrence of within-family divergent cytogenetic features seems to support the polyphyletism proposed for this group.

The shared karyotypic organization observed within Scianidae places it as one of the most cytogenetically conserved Perciformes group. However, the presence of a higher mean heterochromatin content seems to represent a particular trend of this family. This feature indicates an evolutionary pathway dissociated from either chromosomal rearrangements, such as pericentric inversion (the most common rearrangement related to karyotypic diversification within Perciformes), or mechanisms of decrease/increase in diploid number.

\section{ACKNOWLEDGMENTS}

We would like to thank Coordenação de Aperfeiçoamento de Pessoal Docente do Ensino Superior (CAPES), Conselho Nacional de Desenvolvimento Científico e Tecnológico $(\mathrm{CNPq})$, and Universidade Federal do Rio Grande do Norte for the financial support and for providing the facilities and proper conditions for the accomplishment of the present survey.

\section{REFERENCES}

Affonso PR and Galetti PM Jr (2005). Chromosomal diversification of reef fishes from genus Centropyge (Perciformes, Pomacanthidae). Genetica 123: 227-233.

Affonso PRAM, Guedes W, Pauls E and Galetti PM Jr (2001). Cytogenetic analysis of coral reefs fishes from Brazil (Families Pomacanthidae and Chaetodontidae). Cytologia 66: 379-384.

Amores A, Martinez G, Reina J and Alvarez MC (1993). Karyotype, C-banding, and Ag-NOR analysis in Diplodus bellotii 
(Sparidae, Perciformes). Intra-individual polymorphism involving heterochromatic regions. Genome 36: 672-675.

Arkhipchuk VV (1999). Nucleolar variations during the ontogenesis of diploid and tetraploid cyprinid species. J. Fish Biol. 54: 513-524.

Barreto MRC Neto, Oliveira ASS, Affonso PRAM and Pauls E (1998). Cytogenetic studies in marine fishes Pagrus pagrus (Perciformes, Sparidae). In: International Workshop on Marine Genetics, Angra dos Reis, 53.

Brum MJI (1996). Cytogenetic studies of Brazilian marine fish. Braz. J. Genet. 19: 421-427.

Brum MJI and Galetti PM Jr (1997). Teleostei ground plan karyotype. J. Comp. Biol. 2: 91-102.

Cano J, Thode G and Alvarez MC (1981). Analisis cariologico de seis espécies de esparidos del Mediterraneo. Genet. Iber. 33: 181-188.

Cataudella S, Perin Riz P and Sola L (1980). A chromosome study of eight Mediterranean species of Sparidae (Pisces, Perciformes). Genetica 54: 155-159.

Chakraborty SK (1986). Chromosome counts of Nibea semiluctuosa and Johnius belangerii (Pisces: Sciaenidae). Indian J. Fish. 33: 115-118.

Chakraborty SK and Kagwade PV (1989). Somatic chromosomes of two marine teleosts. In: Fish Genetics in India: Proceedings of the Symposium on Conservation and Management of Fish Genetic Resources of India (Das P and Jhingran AG, eds.). Today and Tomorrow's Printers and Publishers, New Delhi, 63-68.

Chanda T (1989). A study of chromosomes in some hill stream fishes of Assam, India. Ph.D. thesis, Kalyani University, Kalyani.

Chao LN (1978). Sciaenidae. In: FAO species identification sheets for fishery purposes. West Atlantic (Fishing Area 31) (Fisher W, ed.). FAO, Rome.

Chao LN (1986). A synopsis on zoogeography of the Sciaenidae. In: Indo-Pacific fish biology: Proceedings of the Second International Conference of Indo-Pacific Fishes (Uyeno T, Arai R, Taniuchi T and Matsuura K, eds.). Ichthyological Society of Japan, Tokyo, 570-589.

Feldberg E, Porto JIR, Santos EBP and Valentim FC (1999). Cytogenetic studies of two freshwater sciaenids of the genus Plagioscion (Perciformes, Sciaenidae) from the central Amazon. Genet. Mol. Biol. 22: 351-356.

Fitzsimons JM and Parker RM (1985). Karyology of the sparid fishes Lagodon rhomboides and Archosargus probatocephalus (Osteichthyes, Perciformes) from coastal Louisiana, North Carolina, and Florida. Proc. LA Acad. Sci. 48: 86-92.

Fitzsimons JM, Rogers JS and Cashner RC (1985). Karyologic and electrophoretic studies of the genus Cynoscion (Sciaenidae, Perciformes) from the northern Gulf of Mexico. Jpn. J. Ichthyol. 31: 444-448.

Froese R and Pauly D (2007). Fishbase. World Wide Web electronic publication. http://www.fishbase.org. Accessed March 22, 2007.

Galetti PM Jr, Aguilar CT and Molina WF (2000). An overview of marine fish cytogenetics. Hydrobiologia 420: 55-62.

Galetti PM Jr, Molina WF, Affonso PR and Aguilar CT (2006). Assessing genetic diversity of Brazilian reef fishes by chromosomal and DNA markers. Genetica 126: 161-177.

Gold JR, Kedzie KM, Bohlmeyer EA, Jenkin JD, et al. (1988). Studies on the basic structure of the red drum (Sciaeniops ocellatus) genome. Contr. Mar. Sci. (Suppl.) 30: 57-62.

Gold JR, Li YC, Shipley NS and Powers PK (1990). Improved methods for working with fish chromosomes with a review of metaphase chromosome banding. J. Fish Biol. 37: 363-575.

Gomes V, Vazzoler AEM and Phan VN (1983a). Estudos cariotípicos de peixes da família Sciaenidae (Teleostei, Perciformes) da região de Cananéia, SP, Brasil. 1. Sobre o cariótipo de Micropogonias furnieri (Desmarest, 1823). Bol. Inst. Oceanogr. 32: 137-142.

Gomes V, Vazzoler AEM and Phan VN (1983b). Estudos cariotípicos de peixes da família Sciaenidae (Teleostei, Perciformes) da região de Cananéia, SP, Brasil. 2. Sobre o cariótipo de Menticirrhus americanus (Linnaeus, 1758). Bol. Inst. Oceanogr. 32: 187-191.

Gregory PE, Howard-Peebles PN and Ellender DR (1980). C-banding of chromosomes from three established marine fish cell lines. Copeia 3: 545-547.

Howell WM and Black DA (1980). Controlled silver-staining of nucleolus organizer regions with a protective colloidal developer: a 1-step method. Experientia 36: 1014-1015.

Jiahan L and Lisha L (1989). Studies on karyotype of Sparus latus Houttuyn. J. Oceanogr. Taiwan Strait 8: 162-166.

Jordan DS and Fesler B (1983). A review of the sparoid fishes of America and Europe. U.S. Fish Commission of Fishes Fisheries Report to the Commissioner 1889-1891, 421-544, plates 28-62.

Khuda-Bukhsh AR and Nayak K (1990). Karyotypic studies in six species of brackish water fishes from India. Kromosomo 58: 1955-1960.

Kim DS, Jeon I-G and Lee JK (1989). Karyotypes, DNA values and nuclear sizes of several scups (Teleostomi: 
Perciformes). Kor. J. lchthyol. 1: 35-41.

Law WM, Elliender RD, Wharton JH and Middlebrooks L (1978). Fish cell culture: Properties of a cell line from the sheepshead, Archosargus probatocephalus. J. Fish. Res. Board Can. 35: 470-473.

Lee MR and Elder FF (1980). Yeast stimulation of bone marrow mitosis for cytogenetic investigations. Cytogenet. Cell Genet. 26: 36-40.

LeGrande WH and Fitzsimons JM (1988). Chromosome numbers of some Gulf Coast sciaenid fishes. Copeia 2: 491-493.

Lin J and Liu L (1989). Studies on karyotype of Sparus latus Houttuyn. J. Oceanogr. Taiwan Strait Taiwan Haixia 8: $162-166$.

Liu J and Tian M (1991). A chromosome study on two sparid fishes (Pagrosomus major and Sparus macrocephalus). Mar. Sci./Haiyang Kexue 3: 64-67.

Manna GK (1989). Fish cytogenetics related to taxonomy, evolution and monitoring aquatic genotoxic agents. Proceedings of the Symposium on Conservation and Management of Fish Genetic Resources in India, April 11-13, 1986, Allahpur, $21-46$.

Molina WF (2001). An alternative method for mitotic stimulation in fish cytogenetics. Chrom. Sci. 5: 149-152.

Molina WF (2006). Chromosomal changes and stasis in marine fish groups. In: Fish cytogenetics (Pisano E, Ozouf-Costaz C, Forest F and Kapoor BG, eds.). Science Publishers, Enfield, 69-110.

Molina WF and Galetti PM Jr (2004). Multiple pericentric inversions and chromosomal divergence in the reef fishes Stegastes (Perciformes, Pomacentridae). Genet. Mol. Biol. 27: 543-548.

Molina WF and Bacurau TOF (2006). Structural and numerical chromosomal variation in marine Perciformes (Priacanthidae and Gerreidae). Cytologia 71: 237-242.

Murofushi M, Nishikawa S and Yoshida TH (1983). Cytogenetical studies on fishes, IV. Karyotypes of six species in the sparoid fishes. Jpn. J. Genet. 58: 361-367.

Nelson JS (2006). Fishes of the World. 4th edn. John Wiley and Sons Inc., New York.

Nishikawa S and Karasawa T (1972). A comparative study of the chromosomes in Japanese fishes, I. A study of the somatic chromosomes of the three species of scups. J. Shimonoseki Univ. Fish. 20: 101-106.

Ojima Y and Kikuno T (1987). Karyotypes of a Gobiesociform and two Perciform fishes (Teleostei). Proc. Jpn. Acad. Ser. B: Phys. Biol. Sci. 63: 201-204.

Orrell TM and Carpenter KE (2004). A phylogeny of the fish family Sparidae (porgies) inferred from mitochondrial sequence data. Mol. Phylogenet. Evol. 32: 425-434.

Patro R and Prasad R (1979). Chromosomes of six marine percoids from the Indian Sea. Indian Biol. 11: 9-12.

Pereira A, Bedó G and Pereira J (1988). Estudio cromosomico preliminar de Micropogonias furnieri Desmarest, 1823 (Perciformes, Sciaenidae). Bol. Soc. Zool. Uruguay $2^{a}$ epoca 4: 23-26.

Pisano E and Ozouf-Costaz C (2000). Chromosome change and the evolution in the Antarctic fish suborder Notothenioidei. Antarct. Sci. 12: 334-342.

Raghunath P and Prasad R (1980). Chromosomes of six marine percoids from the Indian Sea. Ind. Biol. 11: 9-12.

Ramirez SA (1980). A modified technique for fish karyotype analysis using scale epithelium. Copeia (3): 543-545.

Reggi R, Périco E, Suninsky M and Camilo JC de A (1986). Estudos citogenéticos em papa-terra, Menticirrhus litoralis (Perciformes, Serranidae). In: Simpósio de Citogenética Evolutiva e Aplicada de Peixes Neotropicais, Botucatu, SP. Unesp, Botucatu, 57.

Santos S, Hrbek T, Farias IP, Schneider H, et al. (2006). Population genetic structuring of the king weakfish, Macrodon ancylodon (Sciaenidae), in Atlantic coastal waters of South America: deep genetic divergence without morphological change. Mol. Ecol. 15: 4361-4373.

Schultz LP (1953). Family Lutjanidae: Snappers. In: Fishes of the Marshall and Marianas Islands. Bull. U. S. Natl. Mus. 202: 1-685.

Schwarzhans W (1993). A comparative morphological treatise of recent and fossil otoliths of the family Sciaenidae (Perciformes). Piscium catalogus: Part Otolithi Piscium. Verlag Dr. Freidrich Pfeil., München, 1-245.

Sena DC and Molina WF (2007). Robertsonian rearrangements and pericentric inversions in Scaridae fish (Perciformes). Genet. Mol. Res. 6: 575-580.

Sola L and Cataudella S (1978). Prime osservazioni sulla cariologia degli sparidi Mediterranei. Boll. Zool. 45: 242.

Sola L, Cataudella S and Capanna E (1981). New developments in vertebrate cytotaxonomy III. Karyology of bony fishes: A review. Genetica 54: 285-328.

Sumner AT (1972). A simple technique for demonstrating centromeric heterochromatin. Exp. Cell Res. 75: 304-306.

Takai A and Ojima Y (1987). Comparative chromosomal studies in three balistid fishes. Kromosomo 47-48: 1545-1550.

Trewavas E (1977). The sciaenid fishes (croakers or drums) of the Indo-West-Pacific. Trans. Zool. L. 33: 253-541. 
Tripathy NK and Das CC (1988). Karyotypes of Five Indian Perciform Fishes. Copeia 1988: 231-233.

Vasil'ev VP (1978). Karyotypes of five species of fishes (Pisces) from the Black Sea. Tsitologiya (Cytology) 20: 1092-1094.

Vitturi R, Mazzola A, Catalano E and Lo-Conte MR (1992). Karyotype characterization of four Mediterranean sparid fish (Pisces, Perciformes) using conventional and banding techniques. Cytobios 72: 107-115.

Vitturi R, Libertini A, Mazzola A, Colomba MS, et al. (1996). Characterization of mitotic chromosomes of four species of the genus Diplodus: karyotypes and chromosomal nucleolar organizer region phenotypes. J. Fish Biol. 49: $1128-1137$.

Yu Z, Kong X, Xie Z and Wang Y (1993). Studies on the karyotypes and Ag-NOR banding of Pagrosomus major and Sparus macrocephalus. J. Ocean Univ. Qingdao-Qingdao Haiyang Daxue Xuebao 23: 107-115. 